\title{
Proximate Composition, Physical and Sensory Properties of Cake Prepared from Wheat and Cocoyam Flour Blends
}

\author{
Yetunde E. Alozie ${ }^{1}$ \& Chiemela E. Chinma ${ }^{2}$ \\ ${ }^{1}$ Department of Human Ecology, Nutrition and Dietetics, University of Uyo, Nigeria \\ ${ }^{2}$ Department of Food Science and Technology, Federal University of Technology, Minna, Nigeria \\ Correspondence: Yetunde E. Alozie, Department of Human Ecology, Nutrition and Dietetics, University of Uyo, \\ Nigeria. Tel: 234-803-938-5198. Email: tundealozie@yahoo.com
}

\author{
Received: July 5, 2015 Accepted: September 5, 2015 Online Published: September 21, 2015 \\ doi:10.5539/jfr.v4n5p181 \\ URL: http://dx.doi.org/10.5539/jfr.v4n5p181
}

\begin{abstract}
The effect of replacing wheat flour with cocoyam (Xanthosoma sagittifolium) flour on the proximate composition, physical, sensory properties of cake were investigated. Baking trials were conducted at different levels of substitution $(0,20,40,50,60,80$ and 100\%). Cocoyam flour had higher values $(p<0.05)$ in all functional characteristics evaluated except for emulsifying capacity. Cake weights and volume increased with increasing cocoyam flour substitution while volume index decreased. Protein and fat contents of cake samples decreased $(\mathrm{p}<0.05)$ with increasing levels of cocoyam flour substitution while ash and fibre contents increased. There was no significant $(\mathrm{p}>0.05)$ difference in crust colour of samples. In terms of textural preference, cake prepared from $100 \%$ cocoyam flour was significantly higher than $100 \%$ wheat cake. Utilization of wheat-cocoyam flour blends in composite cake preparation will be beneficial to the nutrition of vulnerable groups considering the higher ash and fiber contents of of composite cake, and reduced carbohydrate and fat contents than control.
\end{abstract}

Keywords: Cocoyam flour, cake, composite, wheat flour, physical and sensory properties

\section{Introduction}

Consumption of various bakery and confectionary products is the demand of time due to change in food habit of the people. Cake is one of the relished and palatable baked products prepared from flour, sugar, shortening, baking powder, egg, essence as principal ingredients. Preparation of plain cakes from wheat flour is the conventional practice however, in tropical countries, wheat production is limited and importation of wheat flour to meet local demand is a necessity (Giami et al., 2004). Nowadays, the use of composite flour in which flour from locally grown crops replaces a portion of wheat flour is common in many developing countries to meet the high demand for functional foods with health benefits as well as decreasing the demand for imported wheat and stimulating production and use of locally grown non-wheat agricultural products (UNECA 1985).

Roots and tubers contribute about $20-48 \%$ of the total calories and $7.1 \%$ protein to the diets of the people of sub-Saharan Africa (Nnabuk et al., 2012). Cocoyam is the third most important tuber crop in Nigeria after cassava and yam. Its cultivation spreads from the coastal areas to the savannas. They account for over $50 \%$ of the caloric intake of the people of the south. Cocoyam is fair in protein (7-9\%), yam has less than $6 \%$ protein, cassava is a poor source of protein $(<3 \%)$ while sweet potatoes are poor in protein but fair in their supply of the B-vitamins. Thus cocoyam has some nutritional advantages over other root and tubers crops (Nnabuk et al., 2012). Cocoyam is herbaceous perennial plant belonging to the araceae family and constitutes one of the six most important root and tuber crops world-wide (Ekanem \& Osuji 2006). They are among the major crops grown in wetlands with minimal inputs and offer high potential for alleviating food insecurity and income constraints. The most popular and widely consumed species of cocoyam are the Colocasia, xanthosoma, alocasia, caryotosperma, chamissonis and the amophophallus (Eze \& Okorji 2003). Nutritionally, cocoyam supplies easily digestible starch (Sefa-Dedeh \& Sackey, 2002) and are known to contain substantial amounts of protein, vitamin C, thiamine, riboflavin, niacin and significant amounts of dietary fibre (Niba, 2003). The leaves are cooked and eaten as vegetable. They contain $\beta$-carotene, iron and folic acid which protects against anemia (FAO, 1990; Sukamoto, 2003). Cocoyam is a rich source of carbohydrate, dietary fiber, but low in fat, protein and ash content (Owusu-Darko et al., 2014). Moisture content of cocoyam ranges from 67.1 to $69.17 \%$ 
depending on the specie (Bradbury \& Holloway, 1998). It has been widely reported that cocoyam possesses the smallest starch grain-size relative to other roots and tubers. This makes cocoyam suitable for several food products for potentially allergic infants, persons with gastro-intestinal disorders as well as diabetic patients (Onyenobi et al., 2010). The smallest starch molecules of cocoyam have been associated with increased digestibility over other crops, making it suitable for feeding invalids, production of confectioneries and baby foods (Eneh, 2013). The carbohydrate fraction of cocoyam consists of 2.6 per cent pentosans which makes it a possible alternative for industrial pentosans used in confectionery (Ubalua \& Chukwu, 2008).

Despite the importance and nutritive value of cocoyam in Nigeria and many other nations, its industrial potential as well as its contribution to food security has been grossly under-estimated (Ekwe et al., 2009) as it had been regarded as "poor man's food" or "women crop".

Flours milled from other crops such as maize, millet, sorghum, cassava, plantains, potatoes and rice had been added to wheat flour to extend the use of the local crops and reduce the cost of wheat importation. Several flour samples such as African yam bean, tigernut, moringa and chickpea have been incorporated into wheat flour for cake preparation to provide better overall essential amino acid balance, combat protein energy malnutrition, enhance sensory property and reduce total dependence on imported wheat flour (Alozie et al., 2009; Eke et al., 2009; Chima et al., 2013). Composite flour incorporating cocoyam has been used in extruded products such as noodles and macaroni (FAO, 1990). Opportunities and support for the use of cocoyam flour for production of baked goods if feasible would help to lower the dependency of developing nations on imported wheat. This study was aimed at investigating the proximate composition, physical and sensory properties of cakes prepared from wheat and cocoyam flour blends.

\section{Materials and Methods}

\subsection{Source of Raw Materials}

The study was conducted in the laboratories of the Department of Human Ecology, Nutrition and Dietetics, University of Uyo, Akwa Ibom State, Nigeria. Cocoyam cornels (variety), Wheat Flour (Golden Penny, Nigeria Flour Mills Plc) and cake ingredients (margarine, eggs, granulated sugar, salt and baking powder) were purchased from a local market (Akpanadem) in Uyo metropolis of Akwa Ibom State, Nigeria.

\subsection{Production of Cocoyam Flour (CF)}

Fresh corms were thoroughly washed with tap water, peeled using a stainless steel knife, rewashed and cut into $0.5 \mathrm{~cm}$ thick slices. The slices were blanched at $75^{\circ} \mathrm{C}$ for 15 minutes in potable water. The slices were dried to a constant weight in an oven (Gallenkamp, England) set at $60^{\circ} \mathrm{C}$ for nine hours before milling into flour using a grinder fitted with a $500 \mu \mathrm{m}$ mesh sieve. Flour obtained was packed in Ziploc bags and stored at $4^{\circ} \mathrm{C}$ ready for preparation of composite flours (Njintang et al., 2008).

\subsection{Formulation of Blends}

Wheat flour was substituted with cocoyam flour at substitution levels of 20,40, 50, 60, 80 and100\% labeled A, B, C, D, E and F. Sample with $100 \%$ wheat flour labeled G served as control. A Kenwood mixer was used for mixing flour samples at speed 6 for five minutes to achieve uniform mixing.

\subsection{Proportion of Ingredients}

The proportion of ingredients used consists of flour (400 g), sugar (150g), margarine (250g), eggs (300 g), baking powder $(10 \mathrm{~g})$, salt $(5 \mathrm{~g})$, browning $(10 \mathrm{ml})$ and vanilla essence $(10 \mathrm{ml})$ as described by Ceserani and Kinton (2008) with slight modification (reduction) in the quantity of sugar.

\subsection{Preparation of Cakes}

The method of Ceserani and Kinton (2008) was adopted for the preparation of cake. The margarine and sugar were creamed manually for 10min in a stainless steel bowl until light and fluffy. The egg was beaten for three min and vanilla essence added. It was added to the creamed mixture gradually while beating continued. Flour samples from various composite blends were separately sieved, with salt and baking powder and gradually folded into the mixture with a metal spoon. Browning was added and mixed thoroughly until a soft consistency batter was formed. The batter was transferred to a six inch greased baking pan and baked in a preheated oven at $200^{\circ} \mathrm{C}$ for $30 \mathrm{~min}$ and a further $20 \mathrm{~min}$ at a reduced temperature of $170^{\circ} \mathrm{C}$. A skewer was inserted into the center of the cake to ascertain it is cooked. When cooked, the cakes were allowed to cool in the tin for three minutes before turning out on wire racks for further cooling and analysis. 


\subsection{Functional Properties Determination}

Functional properties of flour such as bulk density was determined using the method of Okezie and Bello (1998), water absorption capacity, swelling capacity and gelatinization temperature were evaluated using the method of Okaka et al. (1997).

\subsection{Proximate Analysis}

Proximate parameters: moisture, protein, crude fibre, fat, ash, carbohydrate and energy values of cake samples were determined according to AOAC (2005). The carbohydrate content was determined by difference while Atwater factors were used to calculate the energy value of the samples. All analysis was carried out in triplicates.

\subsection{Determination of Physical Properties of Cakes}

Volume of cake was determined by seed displacement method, as described by AACC (2000). Volume index of cake samples was measured according to AACC (2000). The cakes were cut vertically through the center and the heights of the cake sample were measured at three different points (B, C and D) along the cross-sectioned cakes using the template (AACC, 2000). According to the method, volume index was determined by the following formula: Volume index $=\mathrm{B}+\mathrm{C}+\mathrm{D}$, where $\mathrm{B}$ and $\mathrm{D}$ are the heights of the cake at the points $2.5 \mathrm{~cm}$ away from the center toward the left and right sides of the cake respectively while $\mathrm{C}$ is the height of the cake at the center point. Weight of cake samples was determined using an electronic digital balance.

\subsection{Sensory Evaluation}

The sensory properties of cakes were evaluated using twenty semi-trained panelists consisting of staff and students of the Department of Human Ecology, Nutrition and Dietetics, University of Uyo, Nigeria. Cakes were evaluated for crust color, flavor, texture, appearance and overall acceptability using nine point Hedonic scale (where $1=$ liked extremely and $9=$ disliked extremely) (Iwe, 2002). A slice of cake from each blend was presented to panelists. Each panelist was provided with a glass of tap water to rinse the mouth between evaluations.

\subsection{Statistical Analysis}

Data obtained was subjected to analysis of variance (ANOVA) (Steel \& Torrie, 1980). Significance difference was accepted at $5 \%$ probability level

\section{Results and Discussion}

\subsection{Functional Properties of Flours}

The functional properties of flours play important role in the manufacturing of products as it determines the application and use of food materials for various food products (Adeleke \& Odedeji, 2010). The result of functional properties of wheat and cocoyam flour is presented in Table 1. Result showed significant differences in functional parameters of the flours except loose bulk density. Cocoyam yam flour had higher values for water and oil absorption capacities, packed bulk density, swelling capacity and gelatinization temperature with low emulsifying capacity compared to wheat flour.

Table 1. Functional properties of wheat and cocoyam flour

\begin{tabular}{llllllll}
\hline & $\begin{array}{l}\text { Water } \\
\text { absorption } \\
\text { capacity } \\
\mathbf{( g / 1 0 0 g )}\end{array}$ & $\begin{array}{l}\text { Swelling } \\
\text { capacity } \\
\mathbf{( \% )}\end{array}$ & $\begin{array}{l}\text { Emulsifying } \\
\text { capacity } \\
\mathbf{( \% )}\end{array}$ & $\begin{array}{l}\text { Gelatinization } \\
\text { Temperature }\end{array}$ & $\begin{array}{l}\text { Oil } \\
\text { absorption } \\
\text { capacity } \\
\mathbf{( g / 1 0 0 g})\end{array}$ & $\begin{array}{l}\text { Loosed } \\
\text { density } \\
(\mathbf{g} / \mathbf{m l})\end{array}$ & $\begin{array}{l}\text { bulk Packed bulk } \\
\text { density } \\
(\mathbf{g} / \mathbf{m l})\end{array}$ \\
\hline Wheat flour & $174.00 \pm 0.00^{\mathrm{b}}$ & $1.60 \pm 0.15^{\mathrm{b}}$ & $17.13 \pm 0.19^{\mathrm{a}}$ & $59.13 \pm 0.29^{\mathrm{b}}$ & $167.0 \pm 0.0^{\mathrm{b}}$ & $0.40 \pm 0.00^{\mathrm{a}}$ & $0.70 \pm 0.00^{\mathrm{b}}$ \\
Cocoyam flour & $182.0 \pm 0.03^{\mathrm{a}}$ & $1.85 \pm 0.05^{\mathrm{a}}$ & $15.23 \pm 0.16^{\mathrm{b}}$ & $69.24 \pm 0.29^{\mathrm{a}}$ & $176.67 \pm 0.28^{\mathrm{a}}$ & $0.40 \pm 0.02^{\mathrm{a}}$ & $0.76 \pm 0.00^{\mathrm{a}}$ \\
\hline
\end{tabular}

Mean values with different superscript in a column are significantly $(\mathrm{p} \leq 0.05)$ different from each other.

Water absorption capacity of flour is an important property in foods. The ability of protein in flours to physically bind water is a determinant of its water absorption capacity (Ikpeme et al., 2010). Flours with high water absorption capacity have been reported to be good ingredients in bakery applications as they improve handling characteristics and lead to improved freshness of baked products (Ma et al., 2011). The values of the water absorption capacity was high in cocoyam flour which may be attributed to its protein subunits structure which 
dissociates on heating in agreement with the findings of Apotiola and Fashakin (2013) that soybean flour protein subunits have more water binding sites.

Oil absorption capacity is an important parameter of flour used in baking (Ikpeme et al., 2010) since it reflects the emulsifying capacity (Kaur et al., 2007) from the industrial viewpoint. Higher oil absorption capacities suggest better mouth feel and flavor retention. The gelling ability of a sample is due to the nature of the starch and protein and their interaction during processing. Variations in the gelling properties of flours have been attributed to the relative ratio of protein, carbohydrates and lipids that make up the flours and interaction between such components (Sathe et al., 1982).

Swelling capacity is often related to protein and starch contents (Woolfe, 1992). Higher protein content in flour may cause the starch granules to be embedded within a stiff protein matrix, which subsequently limits the access of the starch to water and restricts the swelling power (Aprianita et al., 2009). The amylopectin is primarily responsible for granule swelling. Thus, higher swelling capacity of cocoyam flour suggests higher amylopectin content than wheat flour (Tester \& Morrison, 1990). Moorthy and Ramanujam (1986) reported that the swelling power of granules is an indication of the extent of associative forces within granule.

Bulk density is an indication of the porosity of a product and a function of flour wettability which influences packaging design and could be used in determining the required type of packaging material (Iwe \& Onalope 2001; Akubor, 2007). It is also a reflection of the load the sample can carry if allowed to rest directly on another (Onimawo \& Asugo, 2004). The packed bulk density of cocoyam flour in the present study $(0.76 \mathrm{~g} / \mathrm{ml})$ is similar to that observed for taro flour $(0.57-0.71 \mathrm{~g} / \mathrm{ml})$ by Njintang et al. (2007) but higher $(0.43-0.49 \mathrm{~g} / \mathrm{ml})$ than that reported $(0.43-0.49 \mathrm{~g} / \mathrm{ml})$ by Tagodoe and Nip (1994) for taro flour.

\subsection{Physical Properties of Cakes}

The weight and volume of cake samples (Table 2) ranged from 30.0 to $34.6 \mathrm{~g}$, and 225.5 to $259.5 \mathrm{~cm}^{3}$ respectively. Cake weights and volume increased with increasing cocoyam flour levels. This may be attributed to the high packed bulk density of the cocoyam flour. Weights and volumes of baked products have been reported to be dependent on bulk density of the flour blends used (Chinma et al., 2007). Also, increased cake volume could be due to high gas retention thus high expansion of the product which is attributable to high peak viscosity of flour (Chinma et al., 2010). On the other hand, cake volume index of $100 \%$ wheat cake was significantly higher than composite cakes.

Table 2. Physical characteristics of cakes prepared from wheat-cocoyam flour blends

\begin{tabular}{cccc}
\hline Wheat: cocoyam & Cake weight $(\mathbf{g})$ & Cake volume $\left(\mathbf{c m}^{3}\right)$ & Cake volume index \\
\hline $100: 0$ & $30.0 \pm 0.02^{\mathrm{d}}$ & $225.50 \pm 0.01^{\mathrm{e}}$ & $102.5 \pm 0.02^{\mathrm{a}}$ \\
$0: 100$ & $34.6 \pm 0.15^{\mathrm{a}}$ & $259.50 \pm 0.10^{\mathrm{a}}$ & $82.32 \pm 0.01^{\mathrm{e}}$ \\
$80: 20$ & $30.8 \pm 0.22^{\mathrm{c}}$ & $231.25 \pm 0.18^{\mathrm{d}}$ & $94.35 \pm 0.05^{\mathrm{b}}$ \\
$60: 40$ & $32.8 \pm 0.12^{\mathrm{b}}$ & $246.50 \pm 0.02^{\mathrm{c}}$ & $87.45 \pm 0.04^{\mathrm{c}}$ \\
$50: 50$ & $33.0 \pm 0.06^{\mathrm{b}}$ & $247.85 \pm 0.15^{\mathrm{c}}$ & $87.42 \pm 0.03^{\mathrm{c}}$ \\
$40: 60$ & $33.6 \pm 0.23^{\mathrm{b}}$ & $253.84 \pm 0.32^{\mathrm{b}}$ & $84.65 \pm 0.01^{\mathrm{d}}$ \\
$20: 80$ & $34.2 \pm 0.03^{\mathrm{ab}}$ & $256.78 \pm 0.16^{\mathrm{ab}}$ & $83.95 \pm 0.05^{\mathrm{d}}$ \\
\hline
\end{tabular}

Mean values with different superscript in a column are significantly $(\mathrm{p} \leq 0.05)$ different from each other.

\subsection{Proximate Composition of Cakes}

There were no significant differences $(\mathrm{p}>0.05)$ in moisture, protein, fat, ash, fibre, carbohydrate and energy contents between 80: 20 (wheat: cocoyam) cake and control (Table 3). It was observed that protein and fat contents decreased $(\mathrm{p}<0.05)$ with increasing levels of substitution while ash and crude fibre contents increased. Ash is the total mineral content of a food item. The increase in ash content of composite cakes could be attributed to the higher level of ash content in cocoyam flour than wheat flour. The higher crude fibre content of composite cakes may be attributed to higher crude fiber content of cocoyam flour than wheat flour (Ikpeme et al., 2010). 
Table 3. Proximate composition of cakes prepared from wheat-cocoyam flour blends $(\mathrm{g} / 100 \mathrm{~g})$

\begin{tabular}{llllllll}
\hline Parameter & $\mathbf{1 0 0 W F}$ & $\mathbf{1 0 0 C F}$ & $\mathbf{8 0 W F}: 20 \mathrm{CF}$ & $\mathbf{6 0 W F}: 40 \mathrm{CF}$ & $\mathbf{5 0 W F}: 50 \mathrm{CF}$ & 40WF:60CF & 20WF:80CF \\
\hline Moisture & $18.31^{\mathrm{a}}$ & $20.25^{\mathrm{a}}$ & $19.74^{\mathrm{a}}$ & $21.45^{\mathrm{a}}$ & $18.23^{\mathrm{a}}$ & $21.66^{\mathrm{a}}$ & $20.06^{\mathrm{a}}$ \\
Protein & $8.27^{\mathrm{a}}$ & $6.75^{\mathrm{b}}$ & $8.04^{\mathrm{a}}$ & $7.86^{\mathrm{c}}$ & $7.62^{\mathrm{c}}$ & $7.23^{\mathrm{d}}$ & $6.61^{\mathrm{b}}$ \\
Fat & $19.77^{\mathrm{a}}$ & $18.15^{\mathrm{b}}$ & $19.18^{\mathrm{a}}$ & $18.84^{\mathrm{c}}$ & $18.68^{\mathrm{c}}$ & $18.43^{\mathrm{c}}$ & $18.33^{\mathrm{bc}}$ \\
Ash & $1.54^{\mathrm{b}}$ & $1.86^{\mathrm{a}}$ & $1.59^{\mathrm{b}}$ & $1.60^{\mathrm{b}}$ & $1.65^{\mathrm{b}}$ & $1.76^{\mathrm{a}}$ & $1.82^{\mathrm{a}}$ \\
Fibre & $1.24^{\mathrm{a}}$ & $1.48^{\mathrm{a}}$ & $1.27^{\mathrm{a}}$ & $1.33^{\mathrm{a}}$ & $1.36^{\mathrm{a}}$ & $1.40^{\mathrm{a}}$ & $1.45^{\mathrm{a}}$ \\
Carbohydrate & $50.87^{\mathrm{a}}$ & $48.51^{\mathrm{a}}$ & $49.48^{\mathrm{a}}$ & $47.92^{\mathrm{a}}$ & $51.16^{\mathrm{a}}$ & $47.45^{\mathrm{a}}$ & $48.73^{\mathrm{a}}$ \\
Energy(Kcal) & $414.49^{\mathrm{a}}$ & $396.39^{\mathrm{a}}$ & $405.50^{\mathrm{a}}$ & $396.68^{\mathrm{a}}$ & $408.44^{\mathrm{a}}$ & $392.87^{\mathrm{a}}$ & $398.33^{\mathrm{a}}$ \\
\hline
\end{tabular}

Mean values with different superscript in a row are significantly $(\mathrm{p} \leq 0.05)$ different from each other.

$\mathrm{WF}=$ Wheat flour; $\mathrm{CF}=$ Cocoyam flour.

\subsection{Sensory Properties of Cakes}

The result of analysis of selected sensory properties of cakes is shown in Table 4. Values obtained for sensory characteristics of all test products were acceptable by consumers. There was no significant difference in crust color of cake samples. This may be attributed to the color of cocoyam flour which has a brown appearance with increasing amount added to the mixtures. The appearance score of the cakes ranged from 2.15 to 3.95, with cake samples from $100 \%$ cocoyam flour having the highest score while samples from 80:20 wheat-cocoyam flour blends had the lowest and most desirable score. There was significant difference in appearance between control sample and the composite cakes except when $80 \%$ cocoyam flour was substituted. In terms of textural preference, only $100 \mathrm{CF}$ was significantly higher than $100 \mathrm{WF}$. Acceptable cakes can be made with up to $50 \%$ cocoyam flour substitution.

Table 4. Sensory properties of cakes prepared from wheat and cocoyam flour blends

\begin{tabular}{llllllll}
\hline Parameter & $\mathbf{1 0 0 W F}$ & $\mathbf{1 0 0 C F}$ & $\mathbf{8 0 W F}: 20 \mathrm{CF}$ & $\mathbf{6 0 W F}: 40 \mathrm{CF}$ & $\mathbf{5 0 W F}: 50 \mathrm{CF}$ & 40WF:60CF & 20WF:80CF \\
\hline Crust Color & $1.05^{\mathrm{a}}$ & $1.25^{\mathrm{a}}$ & $1.00^{\mathrm{a}}$ & $1.10^{\mathrm{a}}$ & $1.15^{\mathrm{a}}$ & $1.20^{\mathrm{a}}$ & $1.20^{\mathrm{a}}$ \\
Taste & $3.35^{\mathrm{a}}$ & $2.75^{\mathrm{b}}$ & $2.55^{\mathrm{b}}$ & $2.60^{\mathrm{b}}$ & $2.80^{\mathrm{b}}$ & $2.80^{\mathrm{b}}$ & $2.85^{\mathrm{b}}$ \\
Appearance & $2.85^{\mathrm{b}}$ & $3.95^{\mathrm{a}}$ & $2.15^{\mathrm{c}}$ & $2.20^{\mathrm{c}}$ & $2.30^{\mathrm{c}}$ & $2.35^{\mathrm{c}}$ & $2.95^{\mathrm{b}}$ \\
Texture & $2.90^{\mathrm{b}}$ & $3.45^{\mathrm{a}}$ & $2.85^{\mathrm{b}}$ & $2.60^{\mathrm{c}}$ & $2.55^{\mathrm{c}}$ & $2.45^{\mathrm{c}}$ & $2.30^{\mathrm{c}}$ \\
Acceptability & $2.70^{\mathrm{b}}$ & $3.35^{\mathrm{a}}$ & $2.35^{\mathrm{c}}$ & $2.40^{\mathrm{c}}$ & $2.50^{\mathrm{c}}$ & $2.80^{\mathrm{b}}$ & $2.80^{\mathrm{b}}$ \\
\hline
\end{tabular}

Mean value different superscript in a row are significantly $(\mathrm{p} \leq 0.05)$ different from each other.

$\mathrm{WF}=$ Wheat Flour and $\mathrm{CF}=$ Cocoyam Flour.

\section{Conclusion}

The result of the study revealed that substitution of wheat flour with cocoyam flour increased the ash and fibre contents of cake samples. Acceptable cake was produced by substituting wheat flour with cocoyam flour at 20 and 50 per cent vice versa, and could be used for commercial production. This study served as a preliminary investigation on and confirmed the possibility of producing an acceptable cake from wheat and cocoyam flour blends. Acceptable cakes can be prepared with up to 50\% cocoyam flour substitution. Studies are on-going in our laboratory on the nutritional qualities of the composite cakes.

\section{References}

AACC. (2000). Approved methods of the American Association of Cereal Chemists (17th ed.). American Association of Cereal Chemists International, St. Paul, MN.

Adeleke, R. O., \& Odedeji, J. O. (2010). Functional properties of wheat and sweet potato flour blends. Pak. J. Nutr., 9, 535-538. http://dx.doi.org/10.3923/pjn.2010.535.538 
Akubor, P. I. (2007). Chemical, functional and cookie baking properties of soybean/maize flour blends. $J$ Food Sci Technol., 44(6), 619-622.

Alozie, Y. E., Udofia, S., Lawal, O., \& Ani, I. F. (2009). Nutrient composition and sensory properties of cakes made from wheat and African yam bean flour blends. Journal of Food Technology, 7, 115-118.

AOAC. (2005). Association of Official Analytical Chemists (18th ed.). Washington D.C. USA: A.O.A.C.

Apotiola, Z. O., \& Fashakin, J. F. (2013). Evaluation of cookies from wheat flour, soybean flour and cocoyam flour blends. Food Science and Quality Management, 14, 17-21.

Aprianita, A., Purwandari, U., Watson, B., \& Vasiljevic, T. (2009). Physico-chemical properties of flours and starches from selected commercial tubers available in Australia. International Food Research Journal, 16, 507-520.

Bradbury, J. H., \& Holloway, W. D. (1988). Chemistry of tropical root crops: Significance for nutrition and Agriculture in the Pacific. Australian Centre for International Research, Canberra.

Ceserani, V., \& Kinton, R. (2008). Practial Cookery (10th ed.). John Wiley and Sons, New York.

Chinma, C. E., Abu, J. O., \& Abubakar, Y. A. (2010). Effect of tigernut (Cyperus esculentus) flour addition on the quality of wheat-based cake. International Journal of Food Science and Technology, 45, 1746-1752. http://dx.doi.org/10.1111/j.1365-2621.2010.02334.x

Chinma, C. E., Gbadamosi, K. B., Ogunsina, B. S., Oloyede, O. O., \& Salami, S. O. (2014). Effect of addition of germinated Moringa seed flour on the quality attributes of wheat-based cake. Journal of Food Processing and Preservation, 38(4), 1737-1742. http://dx.doi.org/10.1111/jfpp.12136

Chinma, C. E., Ingbian, E. K., \& Akpapunam, M. A. (2007). Processing and acceptability of fried cassava balls ("Akara-akpu") supplemented with melon and soyabean flour. Journal of Food Processing and Preservation, 31, 143-156. http://dx.doi.org/10.1111/j.1745-4549.2007.00117.x

Ekanem, A. M., \& Osuji, J. O. (2006). Mitotic index studies on edible cocoyams (Xanthosoma and Colocasia spp). African Journal of Biotechnology, 5(10), 846-849.

Eke, J., Sanni, S. A., \& Owuno, F. (2009). Proximate and sensory properties of banana cakes. Nigerian Food Journal, 27, 102-106. http://dx.doi.org/10.4314/nifoj.v27i2.47479

Ekwe, K., Nwosu, K., Ekwe, C., \& Nwachukwu, L. (2009). Examining the under explained values of cocoyam (Colocasia and Xanthosoma spp). Nutrition and Economy in Nigeria. In: Jarnieka H., Ganry J., Zeledon Hoeshie I. and Kahara R. (eds). Proceedings of International symposium on underutilized plants for food security, Income and sustainable Development. Acta Horticulture, 86, 71-78

Eneh, O. C. (2013). Towards food security and improved nutrition in Nigeria: Taro (Colocasia antiquorum) grit as carbohydrate supplement in energy food drink. African Journal of Food Science, 7(10), 355-360. http://dx.doi.org/10.5897/AJFS2013.1068

Eze, C. C., \& Okorji, E. C. (2003). Cocoyam production by women farmers under improved and local technologies in Imo state, Nigeria. Africa J. Sci., 5(1), 113-116.

FAO. (1990). Roots, Tubers, Plantains and Bananas in Human Nutrition. Food and Agricultural Organisation, Food and Nutrition series, No.24.

Giami, S. Y., Amasisi, T., \& Ekiyor, G. (2004). Comparison of breadmaking properties of composite flour from kernels of roasted and boiled African breadfruit (Treculia africana decne) seeds. Journal of Raw Material Research, 1, 16-25.

Ikpeme-Emmanuel, C. A., Osuchukwu, N. C., \& Oshiele, L. (2010). Functional and sensory properties of wheat (Aestium triticium) and taro flour (Colocasia esculenta) composite bread. Afr J Food Sci., 4, 248-253

Iwe, M. O. (2002). Handbook of Sensory methods and analysis. Enugu, Nigeria: Rejoint Com. Services Ltd.

Iwe, M. O., \& Onalope, O. O. (2001). Effect of extruded full-fat soy flour into sweet potato flour on functional properties of the mixture. J. Sustain, Agric. Environ., 3, 109-117.

Kaur, M., Singh, N., \& Sandhu, K. S. (2007). Preparation and characterization of protein isolates from different lentil (Lens culinaris) cultivars. J Food Sci Technol., 44, 327-329. 
Ma, Z., Boye, J. I., Simpson, B. K., Prasher, S. O., Monpetit, D., \& Malcolmson, L. (2011). Thermal processing effects on the functional properties and microstructure of lentil, chickpea, and pea flours. Food Research International, 44, 2534-2544. http://dx.doi.org/10.1016/j.foodres.2010.12.017

Moorthy, S. N., \& Ramanujam, T. (1986). Variation in properties of starch in cassava varieties in relation to age of the crop. Starch/Starke, 38, 58-61. http://dx.doi.org/10.1002/star.19860380206

Niba, L. L. (2003). Processing effects on susceptibility of starch to digestion in some dietary starch sources. Int. J. of Food Sci. Nutrition, 54, 97-109. http://dx.doi.org/10.1080/0963748031000042038

Njintang, N. Y., Carl, M. F., Facho, B., Pierre, K., \& Joel, S. (2008). Effect of taro (Colocasia esculenta) flour addition on the functional and alveographic properties of wheat flour and dough. Journal of the Science of Food and Agriculture, 88, 273-279. http://dx.doi.org/10.1002/jsfa.3085

Njintang, Y. N., Mbofung, C. M. F., Moates, K. G., Parker, L., Fauld, C. B., \& Smith, A. C. (2007). Functional properties of five varieties of taro flour and relationship to creep recovery and sensory characteristics of achu (taro based paste). J Food Eng., 82, 114-120. http://dx.doi.org/10.1016/j.jfoodeng.2006.12.023

Nnabuk, O. E., Essien, E., Ebenso, E. E., \& UKPE, R. A. (2012). Industrial potential of two varieties of cocoyam in bread making. E-Journal of Chemistry, 9(1), 451-464. http://dx.doi.org/10.1155/2012/635894

Okaka, J. C., Anosike, G. N., \& Okaka, A. N. C. (1997). Effect of particle size profile of sun-dried and oven dried cowpea flours on their physical and functional characteristics in model system. J. Food Sci. Technol., 3, 65-74.

Okezie, B. O., \& Bello, A. B. (1988). Physicochemical and functional properties of winged bean flour and isolate compared with soy isolate. J. Food Sci., 53(2), 450-454. http://dx.doi.org/10.1111/j.1365-2621.1988.tb07728.x

Onimawo, I. A., \& Asugo, S. (2004). Effects of germination on the nutrient content and functional properties of pigeon pea flour. J Food Sci. Technol., 41(2), 170-174.

Onyenobi, V. O., Chukwu, G. O., Asumogha, G. N., Okoye, B. C., Ewuziem, J. E., Ogbonna, M. C., \& Akpinpelu, A. O. (2010). Marketing of Edible Cocoyam, Xanthosoma spp (Tannia) in Abia State, Nigeria. Cocoyam Research Programme. 2010 Annual Report and Programme of work. NRCRI, Umudike, pp. 69-73.

Opara, L. U. (2002). Edible Aroids: Postharvest Operation. In: AGST/FAO: Danilo, M. (Ed.). Massey University, New Zealand.

Owusu-Darko, P. G., Paterson, A., \& Omenyo, E. L. (2014). Cocoyam (Corms and Cormels)- An under exploited food and feed resource. Journal of Agricultural Chemistry and Environment, 3(1), 22-29. http://dx.doi.org/10.4236/jacen.2014.31004

Sakamoto, L. A. (2003). Development of Early maturing and Leaf Blight Resistant Cocoyam (Colocasia esculenta (L) Schott) with Improved Taste. Proceedings of a Final Research coordination Meeting. Organized by the Joint FAO/IAEA Division of Nuclear Technology in Food and Agriculture Held in Pretoria, South Africa (pp. 19-23).

Sathe, S. K., Deshpande, S. S., \& Salunkhe, D. K. (1982). Functional properties of winged bean proteins. Journal of Food Science, 47, 503-508. http://dx.doi.org/10.1111/j.1365-2621.1982.tb10112.x

Sefa-Dedeh, S., \& Sackey, E. K. (2002). Starch structure and some properties of cocoyam (Xanthosoma sagittifolium and Colocasia esculentum). Food Chemistry, 79, 435-444. http://dx.doi.org/10.1016/S0308-8146(02)00194-2

Tagodoe, A., \& Nip, W. K. (1994). Functional properties of raw and precooked taro (Colocasia esculenta) flours. Int. J. Food Sci. Technol., 29, 457-462. http://dx.doi.org/10.1111/j.1365-2621.1994.tb02087.x

Tester, R. F., \& Morrison, W. R. (1990). Swelling and gelatinisation of cereal starches: Effect of amylopectin, amylose and lipids. Cereal Chemistry, 67, 551-559.

Ubalua, A. O., \& Chukwu, L. I. (2008). Potentials and Constraints of Cocoyam Production in Nigeria Proc. $42^{\text {nd }}$. Conf. Agricultural Society of Nigeria (ASN) October 19 - 232008 (pp. 288-302). Ebonyi State University, Abakaliki, Nigeria.

UNECA. (1985). Technical compendium on composite flours (pp. 67-81). Ethiopia: United Nations Economic Commission for Africa. 
Woolfe, J. (1992). Sweet potato: An untapped food resource (pp. 1-13, 366-372). Cambridge University Press, London.

\section{Copyrights}

Copyright for this article is retained by the author(s), with first publication rights granted to the journal.

This is an open-access article distributed under the terms and conditions of the Creative Commons Attribution license (http://creativecommons.org/licenses/by/3.0/). 